\title{
CHARACTERISTIC OF BROWSING DAMAGES IN NORWAY SPRUCE STANDS
}

\author{
Iveta Desaine ${ }^{1}$, Endijs Bāders², Juris Katrevičs², Jānis Smilga², Jānis Jansons² \\ ${ }^{1}$ Skogssallskapet, Latvia \\ ${ }^{2}$ Latvian State Forest Research Institute 'Silava', Latvia \\ endijs.baders@silava.lv; iveta.desaine@skogssallskapet.com
}

\begin{abstract}
Browsing damages are becoming more common due to almost doubling of population densities of cervids in Latvia during last 20 years; however, the figures are still lower than those observed in western and northern European countries. Consequently, the frequency of damages in young stands is increasing, too. Protection against browsing becomes more difficult, as the trees grow older, also the bark-stripping may result in a long-term deterioration of stem quality. Therefore, the aim of the study was to assess the factors affecting bark striping damages in pole-stage Norway spruce stands. Data were collected in 4 sample plots in damaged Norway spruce stands in western Latvia, measuring the tree parameters: height, diameter, branch characteristics and damage parameters: size, proportion from the stem circumference. Results of the modeling reveal that both damage parameters were significantly influenced by the branch length and thickness in the whorl closest to the breast height and the size of damages - also by breast height diameter of the tree. It suggests that increasing productivity of trees would not reduce the browsing problem. Since the silvicultural goal is the reduction of the size of branches, especially in bottom-log of the stem, protection against bark-stripping needs to be developed and cervid population densities controlled to reduce the problem.
\end{abstract}

Key words: browsing damages, bark striping, branching traits, stem value.

\section{Introduction}

Norway spruce is susceptible to fires, wind storms and bark beetles - factors, causing most of the carbon loss (reducing sequestration) in European forests (Kēnina et al., 2018; Seidl et al., 2014). Fires are affected by the movement of weather systems (Kitenberga et al., 2018) that are formed at a large distance from the Baltic states. They affect the climatic indices, for example, drought (that can be also described by potential evapotranspiration) and they, in turn, are linked to the flammability of the material in forest floor (litter) affecting the probability of forest fore to occur, if ignition source is present. Ignition nowadays is usually caused by human activity (or in-action), rather than natural factors, like lightening (Donis et al., 2017). Once the fire has started, the efficiency of fire protection system determines its size - no correlation between it and climatic variables had been noted (Donis et al., 2017). Norway spruce with the thin bark and shallow root system is easily killed in a forest fire. A shallow root system is also the reason this tree species is often affected in wind storms. They cause sizable losses for forest owners; therefore, after most of the largest storms suggestions to replace Norway spruce with other tree species occur. Due to its wood quality and fast growth, feasible alternatives are hard to find though. One of such alternatives could be a hybrid aspen, but it is also notably affected by biotic as well as abiotic factors (Zeps et al., 2017; Senhofa et al., 2017; Šēnhofa et al., 2016a). Establishment of mixed stands is also suggested to increase resilience (Lindner et al., 2008) as well as use of wider spacing in regeneration. Wider spacing may have a positive effect on radial increment (Katrevičs et al., 2018) also ensuring the potential to reduce the length of rotation period while applying the cutting by a target diameter. However, it might be couples with lower external and internal (Jansons et al., 2017a) branch quality of trees. Spruces, affected by abiotic factors, like wind storms or drought (Zeltiňs et al., 2016; 2018) are more prone to damages by biotic factors, primarily - fungus (Neimane et al., 2018; Burnēviča et al., 2016; Jansons et al., 2016; Arhipova et al., 2015) and dendrophagous insects. Climatic conditions for bark beetles has been improving - more than one generation per year for this insect is becoming increasingly more common (Šmits, personal communication). Ongoing changes in climatic conditions may have a positive effect also on the tree growth - as suggested by the dendrochronological analysis (Jansons et al., 2013a; 2013b; 2015a; 2015b; Šēnhofa et al., 2018; 2016b) and global predictions. Additionally, increment of Norway spruce as well as for other tree species is at least partly genetically determined (Jansons, 2005; Jansons et al., 2006); it can be significantly increased while applying selected plant material (mainly - seed orchard progenies). Financial efficiency of breeding of numerous tree species is high (Jansons, Gailis, \& Donis, 2011; Gailis \& Jansons, 2010; Jansons et al., 2015c); however, it is notably dependent on use of the area regenerated by the material from the breeding programs annually. This, in turn, is affected by the regeneration costs for the forest owner (Dzerina et al., 2016), including costs of supplemental planting, linked to browsing (Lazdins, Lazdina, \& Liepa, 2010). Browsing is an increasing problem both in state and private forests, as suggested by the results of the monitoring of browsing damages, carried out by LSFRI Silava. Data of state forest service suggest almost doubling of population densities of cervids in 


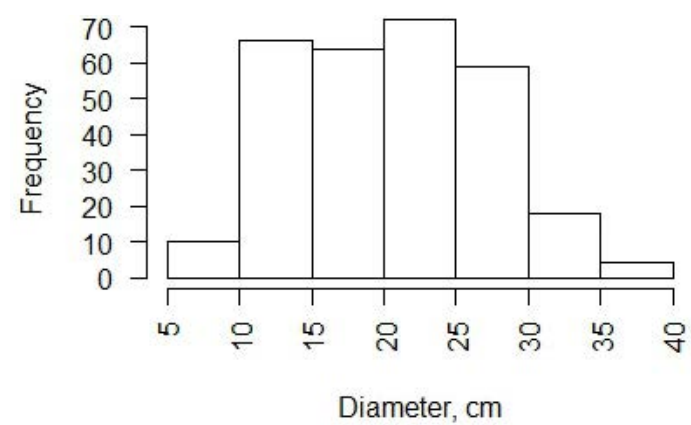

Figure 1. Histogram of diameter distribution in the evaluated Norway spruce stands.

Latvia during last 20 years; however, the figures are still lower than those observed in primarily western European countries, suggesting that the trend might continue. Repellents and their application is additional costs for the forest owners. Bark striping may reduce survival of trees in plantation as well as reduce the stem quality, causing crookedness and wood discoloration and/or decay. The repellents against this type of damages so far had not been well worked out. Advanced regeneration of Norway spruce, being one of the mechanism of regeneration of this tree species also in larger-scale openings created e.g. by storm (Baders et al., 2017a; Jogiste et al., 2017) or clearcutting, might be less affected by browsing, but the bark of trees at the pole-stage stands are similar of that of planted trees, thus may not provide any protection against barks striping. The impact of this damage may accumulate over time, since: a) research suggests that some individual trees are preferred by cervids and might be browsed from year to year; 2) healing of damages takes time (Baders et al., 2017b) and additional damages might be caused. Limited information is available on the impact of browsing damages on increment of the trees older than 20 years. To better understand the situation in the affected stands and thus set the stage for further research, the aim of the study was to assess the factors affecting bark striping damages in pole-stage Norway spruce stands. Tree-level factors were the subject of this study.

\section{Materials and Methods}

Data were collected in 4 sample plots (are $400 \mathrm{~m}^{2}$ ) in damaged pure Norway spruce stands at the age of 45 years in Hylocomiosa forest type western Latvia, affected by browsing c.a. 15 years ago. The measured parameters for every tree were:

1) diameter at breast height $(1.3 \mathrm{~m}), \mathrm{cm}(\mathrm{Dcm})$

2) height, $\mathrm{m}(\mathrm{Hm})$

3) height of first living branch, $m$ (HZZm)

4) height of first dry branch, m (HSZm)

5) mean diameter of the branch in whorl closest to breast height (ZD1_3)

6) mean length of the branch in whorl closest to breast height (ZG1_3)
7) number of branches in first $2 \mathrm{~m}$ of the stem (Zsk)

The whorl closes to breast height and the first twometer section had been chosen, since it is the part of the stem affected by bark striping.

Area without bark (largest continuous damage) and its portion from circumference of the stem in most affected height was estimated.

The current distribution of stem diameters is as shown in Figure 1.

ANOVA analysis was used to assess significant differences between sampleplots. To assess correlations between factors we used Pearson correlation. The generalized linear mixed-effects model, with Poisson distribution was used to assess relationships between damage severity and tree characteristics. The sample plot was included in model as random factor. We used backward variable selection. The final model selection was based on the lowest AIC values. All calculations were done in R (R Development Core Team 2016) using packages "lme4" (Bates et al., 2015) and "ltm" (Rizopoulos, 2006).

\section{Results and Discussion}

The mean diameter of spruce was $18.1 \mathrm{~cm}$ and the stands were rather dense, with a good survival. The number of damaged trees varied from 37 in the sample plot 2 to 63 in the sample plot 1 , while the percentage of damaged trees varied from $42.5 \%$ in the sample plot 2 to $66.3 \%$ in the sample plot 1 (Table 1). Significant differences in the number of damaged trees $(\mathrm{p}<0.05)$ (Fig.2 C) were found only between the sample plot 1 and the sample plot 2 .

The mean height of the first live branch was $12.7 \mathrm{~m}$, significant differences were found between the sample plot 4 and sample plot 1 , as well as the plot 4 and plot 3 $(\mathrm{P}<0.05)$. The mean highest live branch was observed in the plot $4(13.7 \mathrm{~m})$; however, the lowest one was in the plot $1(11.8 \mathrm{~m})$. The mean height of spruce trees was $19.2 \mathrm{~m}$, no significant differences between sample plots were observed (Fig. 2B). Also, no significant differences between sample plots for other measured variables were found. The mean height of the first dry branch was $0.32 \mathrm{~m}$, the mean diameter of whorl 


\section{Level of browsing damages in the plots}

\begin{tabular}{|c|c|c|c|}
\hline Plot No & Number of trees & Number of damaged trees & Proportion of damaged trees \% \\
\hline 1 & 95 & 63 & 66.3 \\
\hline 2 & 87 & 37 & 42.5 \\
\hline 3 & 93 & 57 & 61.3 \\
\hline 4 & 111 & 53 & 47.7 \\
\hline
\end{tabular}

Table 2

Pearson correlation (upper diagonal part shows coefficients, lower diagonal part shows their p-values) calculated between different analysed factors

\begin{tabular}{|l|c|c|c|c|c|c|c|}
\hline & Dcm & Hm & HZZm & HSZm & ZD1_3 & ZG1_3 & ZSk \\
\hline Dcm & $* * * * *$ & 0.808 & 0.264 & -0.105 & 0.405 & 0.274 & -0.052 \\
\hline Hm & $<0.001$ & $* * * * *$ & 0.622 & -0.086 & 0.309 & 0.167 & -0.098 \\
\hline HZZm & $<0.001$ & $<0.001$ & $* * * * *$ & -0.123 & 0.121 & -0.027 & -0.011 \\
\hline HSZm & 0.078 & 0.148 & 0.039 & $* * * * *$ & -0.154 & -0.184 & -0.37 \\
\hline ZD1_3 & $<0.001$ & $<0.001$ & 0.039 & 0.009 & $* * * * *$ & 0.609 & 0.243 \\
\hline ZG1_3 & $<0.001$ & 0.004 & 0.642 & 0.002 & $<0.001$ & $* * * * *$ & 0.342 \\
\hline ZSk & 0.376 & 0.096 & 0.851 & $<0.001$ & $<0.001$ & $<0.001$ & $* * * * *$ \\
\hline
\end{tabular}

Dcm - diameter, cm; Hm - height, m; HZZm - height of the first living branch; HSZm - height of the first dry branch; ZD1_3 - mean diameter of the branch in the whorl closest to the breast height; ZG1_3 - mean length of the branch in the whorl closest to the breast height; Zsk - the number of branches in the first $2 \mathrm{~m}$ of the stem.
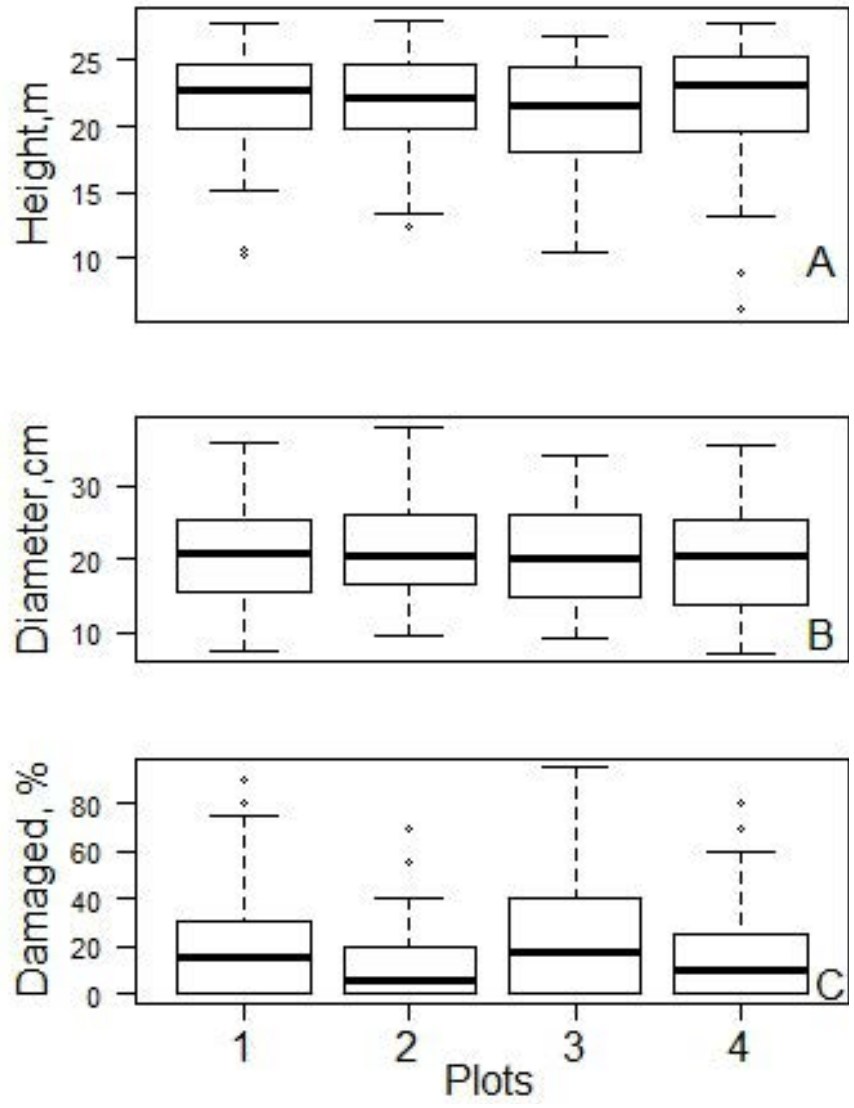

Figure 2. Descriptive of sample plots, A - mean height, B - mean diameter (cm), C - damaged trees (\%). 
Models characterizing factors affecting bark striping damages

\begin{tabular}{|l|c|c|c|c|c|}
\hline \multicolumn{1}{|c|}{ Parameter } & $\begin{array}{c}\text { Variance of } \\
\text { random factor }\end{array}$ & Variables & Estimate & std. error & $\mathrm{p}$-value \\
\hline \multirow{2}{*}{$\begin{array}{l}\text { Largest continuous } \\
\text { damaged area }\end{array}$} & \multirow{2}{*}{0.011} & Intercept & 0.77 & 0.16 & $\mathrm{p}<0.0001$ \\
\cline { 3 - 6 } & & DCm & 0.035 & 0.006 & $\mathrm{p}<0.0001$ \\
\cline { 3 - 6 } & ZG1_3 & -0.63 & 0.177 & $\mathrm{p}<0.0003$ \\
\hline $\begin{array}{l}\text { Proportion of damage } \\
\text { from the circumference of } \\
\text { the stem }\end{array}$ & 0.033 & Intercept & 3.74 & 0.103 & $\mathrm{p}<0.0001$ \\
\cline { 3 - 6 } & & ZD1_3 & -0.08 & 0.004 & $\mathrm{p}<0.0001$ \\
\hline
\end{tabular}

D cm - diameter, cm; ZD1_3 - mean diameter of whorl branches at breast height.

branches at the breast height was $10.4 \mathrm{~mm}$, the mean length of whorl branches at the breast height was $0.54 \mathrm{~m}$ and the mean number of branches until height of $2 \mathrm{~m}$ was 28 branches.

Significant correlations were found between many predictors (Table 2) that were considered, while constructing the model. The strongest positive correlations were found between diameter and height $(\mathrm{P}=0.8, \mathrm{p}<0.01)$, height and height of the first live branch $(\mathrm{P}=0.6, \mathrm{p}<0.001)$, mean diameter of whorl branches at the breast height and the mean length of whorl branches at the breast height $(\mathrm{P}=0.6$, $\mathrm{p}<001)$.

GLMER analysis showed that the maximal proportion of damage from the circumference of the stem (\%) was significantly negatively affected by the mean diameter of the branch in the whorl closest to the breast height $(\mathrm{p}<0.001)$. The causal link presumably being that ticker branches minimize the probability that the animal will have access to all sides of the tree - thus, if browsing occurs, then only on the limited part of the stem.

The largest continuous area of bark stripping was significantly positively affected by tree diameter $(p<0.001)$ while, the mean length of the branch in the whorl closest to the breast height had a significant negative influence. The breast height diameter might have a double influence on the area of damages of the diameter is larger, there is more space for bark stripping; and if the tree is larger (presumably - faster growing) the bark stripping can start a few years earlier. To distinguish between these factors, increment cores shall be collected and analysed, but this was not part of this study.

The mean length of the branch in the whorl closest to the breast height might have a similar influence as the branch diameter, preventing the accessibility to the stem. In both cases, the factors actually having a negative influence on browsing are with the negative silvucultural influence - the main interest of the forest owner is to heave the highest quality of the bottom log of the tree (the largest portion from the stem volume) to sell it for the highest price. Thus, both in tree breeding and precommercial thinnigs trees with the largest branches are excluded. Our results indicated, that this may lead to even higher impact of bark stripping.

\section{Conclusions}

1. Assessment of Norway spruce stands, where half (on average 54\%) of the trees had browsing damages reveal that both the size (area) and proportion of the damage from the circumference of the stem were affected by branch parameters at the height of the damages.

2. Continuous improvement of branch quality and reduction of browsing damages is possible only with the use of repellents.

\section{Acknowledgements}

The study was supported by Sate research program ResProd (No 2014.10-4/VPP-6/6) and ERDF postdoctoral project "Measures to increase resilience of Norway spruce forests against the impact of climatic changes" (No 1.1.1.2/VIAA/1/16/120)

\section{References}

1. Arhipova, N., Jansons, A., Zaluma, A., Gaitnieks, T., \& Vasaitis, R. (2015). Bark stripping of Pinus contorta caused by moose and deer: wounding patterns, discoloration of wood, and associated fungi. Canadian Journal of Forest Research. 45, 1434-1438.

2. Baders, E., Donis, J., Snepsts, G., Adamovics, A., \& Jansons, A. (2017a). Pruning effect on Norway spruce (Picea abies (L.) Karst.) growth and quality. Forestry Studies. 66, 33-48.

3. Baders, E., Senhofa, S., Purina, L., \& Jansons, A. (2017b). Natural succession of Norway spruce stands in hemiboreal forests: case study in Slitere national park, Latvia. Baltic Forestry. 23 (2), 522-528. 
4. Bates, D., Maechler, M., Bolker, B., \& Walker, S. (2015). Fitting Linear Mixed-Effects Models Using lme4. Journal of Statistical Software. 67(1), 1-48. DOI: 10.18637/jss.v067.i01.

5. Burneviča, N., Jansons, Ā., Zaḷuma, A., Kḷaviņa, D., Jansons, J., \& Gaitnieks, T. (2016). Fungi inhabiting bark stripping wounds made by large game on stems of Picea abies (L.) Karst. in Latvia. Baltic Forestry. 22, 2-7.

6. Donis, J., Kitenberga, M., Snepsts, G., Matisons, R., Zarins, J., \& Jansons, A. (2017). The forest fire regime in Latvia during 1922-2014. Silva Fennica. 51 (5). DOI: 10.14214/sf.7746.

7. Dzerina, B., Girdziusas, S., Lazdina D., Lazdins, A., Jansons, J., Neimane, U., \& Jansons, Ā. (2016). Influence of spot mounding on height growth and tending of Norway spruce: case study in Latvia. Forestry Studies. 65, 24-33.

8. Gailis, A., \& Jansons, Ā. (2010). Results of black alder (Alnus glutinosa (L.) Gaertn.) improvement in Latvia. In Gaile, Z. (ed.): Proceedings of the 16th international scientific conference Research for Rural Development, 19 to 21 May 2010 (pp. 255-260). Jelgava, Latvia: LLU.

9. Jansons, Ā. (2005). Distinguish between the effect of seed material and forest type on Scots pine stand productivity. In Gaile, Z. (ed.): Proceedings of the international scientific conference Research for Rural Development, 19-22 May, 2005 (pp. 227-233). Jelgava, Latvia: LLU.

10. Jansons, Ā., Baumanis, I., Dreimanis, A., \& Gailis, A. (2006). Variability and genetic determination of Scots pine quantitative traits at the age of 32 years. In Gaile, Z. (ed.): Proceedings of the international scientific conference Research for Rural Development, 19-22 May, 2006 (pp. 289-295). Jelgava, Latvia: LLU.

11. Jansons, A., Donis, J., Danusevičius, D., \& Baumanis, I. (2015c). Differential analysis for next breeding cycle for Norway spruce in Latvia. Baltic Forestry. 21 (2), 285-297.

12. Jansons, Ā., Gailis, A., \& Donis, J. (2011). Profitability of silver birch (Betula pendula Roth.) breeding in Latvia. In: Z. Gaile (ed.) Proceedings of the $17^{\text {th }}$ international scientific conference Research for Rural Development, 18-20 May 2011 (pp. 33-38). Jelgava, Latvia: LLU.

13. Jansons, A., Matisons, R., Baumanis, I., \& Purina, L. (2013b). Effect of climatic factors on height increment of Scots pine in experimental plantation in Kalsnava, Latvia. Forest Ecology and Management. 306, 185-191.

14. Jansons, A., Matisons, R., Libiete-Zālīte, Z., Baders, E., \& Rieksts-Riekstiňš, J. (2013a). Relationships of height growth of Lodgepole pine (Pinus contorta var. latifolia) and Scots pine (Pinus sylvestris) with climatic factors in Zvirgzde, Latvia. Baltic Forestry. 19(2), 236-244.

15. Jansons, A., Matisons, R., Pobiarzens, A., Sisenis, L., \& Neimane, U. (2017a). Proportion of knotty wood in stems of 28-year old lodgepole and Scots pine in experimental plantation in Zvirgzde, Latvia. Folia Forestalia Polonica. series A - Forestry, 59 (3), 181-188.

16. Jansons, Ā., Matisons, R., Puriņa, L., Neimane, U., \& Jansons, J. (2015b). Relationships between climatic variables and tree-ring width of European beech and European larch growing outside of their natural distribution area. Silva Fennica. 49 (1), 8 p.

17. Jansons, A.., Matisons, R., Zadina, M., Sisenis, L., \& Jansons, J. (2015a). The effect of climatic factors on height increment of Scots pine in sites differing by continentality in Latvia. Silva Fennica. 49 (3), 14 p.

18. Jansons, Ā., Neimane, U., Polmanis, K., Zalıuma, A., Gaitnieks, T., \& Baumanis, I. (2016). Cumulative effect of needle cast on Scots pine saplings. Forestry Studies. 65, 5-15.

19. Jogiste, K., Korjus,H.,Stanturf, J.A., Frelich, L., Baders, E., Donis, J., Jansons, A., Kangur, A., Koster, K., Laarmann, D., Maaten, T., Marozas, V., Metslaid, M., Nigul, K., Polyachenko, O., Randveer, T., \& Vodde, F. (2017) Hemiboreal forest: natural disturbances and the importance of ecosystem legacies to management. Ecosphere. 8, DOI: 10.1002/ecs2.1706.

20. Katrevičs, J., Džerina, B., Neimane, U., Desaine, I., Bigača, Z., \& Jansons, Ā. (2018). Production and profitability of low density Norway spruce (Picea abies (L.) Karst.) plantation at 50 years of age: case study from eastern Latvia. Agronomy Research. 16, DOI: 10.15159/AR.18.014.

21. Ķēniņa, L., Elferts, D., Bāders, E., \& Jansons, Ā. (2018). Carbon pools in a hemiboreal over-mature Norway spruce stands. Forests. 9, DOI: 10.3390/f9070435.

22. Kitenberga, M., Matisons, R., Jansons, A., \& Donis, J. (2018). Teleconnection between the Atlantic sea surface temperature and forest fires in Latvia and Estonia. Silva Fennica. 52 (1), 8 p. DOI: 10.14214/ sf.7771.

23. Lazdins, A., Lazdina, D., \& Liepa, I. (2010). Characterization of naturally afforested farmlands in Latvia. In Gaile, Z. (ed.): Proceedings of the 16th international scientific conference Research for Rural Development, 19 to 21 May 2010 (pp. 176-182). Jelgava, Latvia: LLU. 
24. Lindner, M., Garcia-Gonzalo, J., Kolström, M., Green, T., Reguera, R., Maroschek, M., \& Kremer, A. (2008). Impacts of climate change on European forests and options for adaptation. Report to the European Commission Directorate-General for Agriculture and Rural Development. Rome: EK (173).

25. Neimane, U., Polmanis, K., Zaļuma, A., Kḷaviņa, D., Gaitnieks, T., \& Jansons, Ā. (2018). Damage caused by Lophodermium needle cast in open-pollinated and control-crossed progeny trials of Scots pine (Pinus sylvestris L.). The Forestry Chronicle. 94, DOI: 10.5558/tfc2018-02.

26. R Core Team (2016). R: a language and environment for statistical computing. R Foundation for Statistical Computing, Vienna, Austria. Retrieved April 10, 2018, from: https://www.R-project.org/.

27. Rizopoulos, D. (2006). ltm: An R package for Latent Variable Modelling and Item Response Theory Analyses, Journal of Statistical Software. 17 (5), 1-25. URL Retrieved April 8, 2018, from: http://www. jstatsoft.org/v17/i05/.

28. Seidl, R., Schelhaas, M-J., Rammer, W., \& Verkerk, P.J. (2014). Increasing forest disturbances in Europe and their impact on carbon storage. Nature Climate Changes. 4, DOI: 0.1038/nclimate2318.

29. Senhofa, S., Neimane, U., Grava, A., Sisenis, L., Lazdina, D., \& Jansons, A. (2017). Juvenile growth and frost damages of poplar clone OP42 in Latvia. Agronomy Research. 15, 2113-2125, DOI: 10.15159/ AR.17.061.

30. Šēnhofa, S., Zeps, M., Gailis, A., Kāpostiņš, R., \& Jansons, Ā. (2016). Development of stem cracks in young hybrid aspen plantations. Forestry Studies. 65.

31. Šēnhofa, S., Zeps, M., Ķēniņa, L., Neimane, U., Kāpostiņš, R., Kārkliņa, A., \& Jansons, Ā. (2018). Intraannual height growth of hybrid poplars in Latvia. Results from the year of establishment. Agronomy Research. 16, 254-262, DOI: 10.15159/AR.17.073.

32. Šēnhofa, S., Zeps, M., Matisons, R., Smilga, J., Lazdina, D., \& Jansons, Ā. (2016). Effect of climatic factors on tree ring width of Populus hybrids in Latvia. Silva Fennica. 50 (1), 12 p.

33. Zeltiņš, P., Katrevičs, J., Gailis, A., Maaten, T., Bāders, E., \& Jansons, Ā. (2018). Effect of stem diameter, genetics, and wood properties on stem cracking in Norway spruce. Forests. 9, DOI: 10.3390/f9090546.

34. Zeltiņš, P., Katrevičs, J., Gailis, A., Maaten, T., Jansons, J., \& Jansons, Ā. (2016). Stem cracks of Norway spruce (Picea abies (L.) Karst.) provenances in Western Latvia. Forestry Studies. 65, 57-63.

35. Zeps, M., Senhofa S., Zadina, M., Neimane, U., \& Jansons, A. (2017). Stem damages caused by heart rot and large poplar borer on hybrid and European aspen. Forestry Studies. 66, 21-26. 